\title{
Consensus Multilocus Sequence Typing Scheme for Pneumocystis jirovecii
}

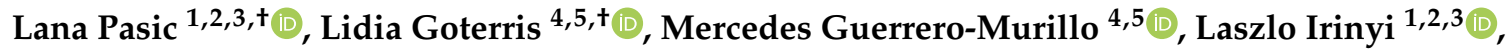 \\ Alex Kan ${ }^{1,2,3}{ }^{\mathbb{D}}$, Carolina A. Ponce ${ }^{6}\left(\mathbb{D}\right.$, Sergio L. Vargas ${ }^{6}\left(\mathbb{D}\right.$, M. Teresa Martin-Gomez ${ }^{4,5}$ \\ and Wieland Meyer 1,2,3,7,*(D) \\ 1 Molecular Mycology Research Laboratory, Centre for Infectious Diseases and Microbiology, \\ Westmead Clinical School, Sydney Medical School, Faculty of Medicine and Health, \\ The University of Sydney, Sydney 2006, Australia; lana.pasic@sydney.edu.au (L.P.); \\ laszlo.irinyi@sydney.edu.au (L.I.); alex.kan@sydney.edu.au (A.K.) \\ 2 Marie Bashir Institute for Infectious Diseases and Biosecurity, The University of Sydney, \\ Sydney 2006, Australia \\ 3 Westmead Institute for Medical Research, Westmead 2145, Australia \\ 4 Microbiology Department, Hospital Universitari Vall d'Hebron (VHUH), 08035 Barcelona, Spain; \\ lgoterris@vhebron.net (L.G.); mercedes.guerrero@vhir.org (M.G.-M.); mtmartin@vhebron.net (M.T.M.-G.) \\ 5 Genetics and Microbiology Department, Universitat Autònoma de Barcelona (UAB), 08035 Barcelona, Spain \\ 6 Instituto de Ciencias Biomédicas (ICBM), Facultad de Medicina, Universidad de Chile, \\ Santiago de Chile 8380453, Chile; cponce@med.uchile.cl (C.A.P.); svargas@med.uchile.cl (S.L.V.) \\ 7 Westmead Hospital (Research and Education Network), Westmead 2145, Australia \\ * Correspondence: wieland.meyer@sydney.edu.au; Tel.: +61-2-86273430 \\ + These authors contributed equally to this work.
}

Received: 10 September 2020; Accepted: 18 October 2020; Published: 30 October 2020

\begin{abstract}
Pneumocystis jirovecii is an opportunistic human pathogenic fungus causing severe pneumonia mainly in immunocompromised hosts. Multilocus sequence typing (MLST) remains the gold standard for genotyping of this unculturable fungus. However, the lack of a consensus scheme impedes a global comparison, large scale population studies and the development of a global MLST database. To overcome this problem this study compared all genetic regions (19 loci) currently used in 31 different published Pneumocystis MLST schemes. The most diverse/commonly used eight loci, $\beta$-TUB, CYB, DHPS, ITS1, ITS1/2, $m t 26 S$ and SOD, were further assess for their ability to be successfully amplified and sequenced, and for their discriminatory power. The most successful loci were tested to identify genetically related and unrelated cases. A new consensus MLST scheme consisting of four genetically independent loci: $\beta-T U B, C Y B, m t 26 S$ and $S O D$, is herein proposed for standardised $P$. jirovecii typing, successfully amplifying low and high fungal burden specimens, showing adequate discriminatory power, and correctly identifying suspected related and unrelated isolates. The new consensus MLST scheme, if accepted, will for the first time provide a powerful tool to investigate outbreak settings and undertake global epidemiological studies shedding light on the spread of this important human fungal pathogen.
\end{abstract}

Keywords: $P$. jirovecii; consensus MLST scheme; $\beta$-TUB; CYB; $m t 26 S$ and SOD

\section{Introduction}

Pneumocystis jirovecii is a major opportunistic pathogen, which can manifest into severe pneumonia, Pneumocystis pneumonia (PCP), in immunocompromised patients. PCP can cause interstitial lung disease, along with fever, coughs and dyspnea [1]. The incidence is still relatively high, especially in the developing world, for this underestimated fungus, with reported mortality rates ranging from 
$10 \%$ to $60 \%[2,3]$. Besides causing isolated cases, $P$. jirovecii has been linked to nosocomial outbreaks affecting mainly solid organ transplant recipients with devastating consequences. Besides helping to establish epidemiological links among affected patients, allowing for paths of transmission to be mapped and index cases identified within hospital outbreaks, genotyping is an essential tool to achieve knowledge on more general aspects of the epidemiology of microorganisms.

Multilocus sequence typing (MLST) is currently the preferred standard for genotyping, due to the limited amounts of DNA being available from this unculturable fungus in clinical samples, its reproducibility, inexpensiveness and discriminatory ability [4]. However, unlike many other human pathogenic fungi, Pneumocystis has, as yet, no consensus typing scheme, which hinders the ability for global comparison of clinical isolates, since multiple various typing schemes are currently in use [5].

There are 19 coding and non-coding DNA regions which have been explored for Pneumocystis genotyping world-wide. The levels of allelic polymorphism fluctuate greatly between the used DNA regions, resulting in varying levels of discriminatory power among 31 schemes currently reported in the literature (see Table 1) [3,5-71]. The lack of standardisation limits the interpretation and comparison of different epidemiological datasets and studies. Molecular typing of P. jirovecii is further hampered by the fact that the fungus cannot be cultured in vivo, and hence the volume of DNA available for sequencing analysis is limited [72]. The DNA volume can be further depleted depending on the source and site of extraction, and if the patients are having a mild infection or if they are colonised carriers [73]. Therefore, the ability of a locus to be successfully amplified is equally as important as it is discriminatory power, when deliberating which loci to include in a standardised MLST scheme. 
Table 1. Published genetic loci used in P. jirovecii genotyping, corresponding multilocus sequence typing (MLST) schemes and obtained allele and sequence types. MLST schemes described are listed chronologically, followed by the respective publications using the specific scheme. The third column indicates the total number of isolates included in the study, followed by the fourth column, which indicates the number of isolates which were able to be successfully sequenced by the study. The fifth column lists the total number of sequence types identified, with the following columns listing the number of allele types found for each genetic locus.

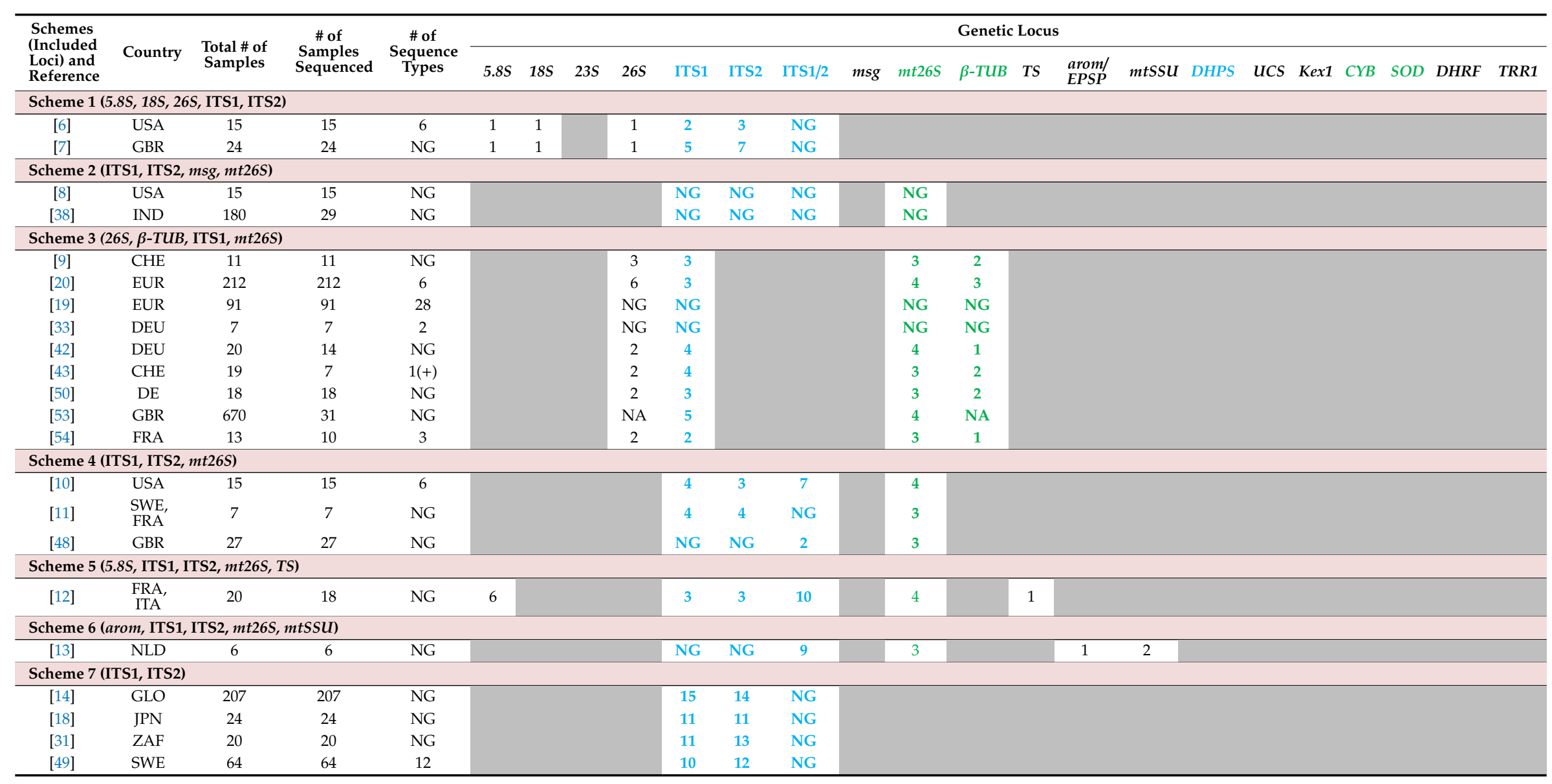


Table 1. Cont

\begin{tabular}{|c|c|c|c|c|c|c|c|c|c|c|c|c|c|c|c|c|c|c|c|c|c|c|c|c|}
\hline \multirow{2}{*}{$\begin{array}{l}\text { Schemes } \\
\text { (Included } \\
\text { Loci) and } \\
\text { Reference }\end{array}$} & \multirow{2}{*}{ Country } & \multirow{2}{*}{$\begin{array}{l}\text { Total \# of } \\
\text { Samples }\end{array}$} & \multirow{2}{*}{$\begin{array}{c}\text { \# of } \\
\text { Samples } \\
\text { Sequenced }\end{array}$} & \multirow{2}{*}{$\begin{array}{c}\text { \# of } \\
\text { Sequence } \\
\text { Types }\end{array}$} & \multicolumn{20}{|c|}{ Genetic Locus } \\
\hline & & & & & $5.8 \mathrm{~S}$ & $18 S$ & $23 S$ & $26 \mathrm{~S}$ & ITS1 & ITS2 & ITS $1 / 2$ & $m s g$ & $m t 26 \mathrm{~S}$ & $\beta$-ТИВ & $T S$ & $\begin{array}{l}\text { arom/ } \\
E P S P\end{array}$ & $m t S S U$ & DHPS & UCS & Kex1 & $C Y B$ & $S O D$ & DHRF & TRR1 \\
\hline \multicolumn{25}{|c|}{ Scheme 8 (DHPS, ITS1, ITS2, $m t 26 S)$} \\
\hline [15] & FRA & 14 & 14 & NG & & & & & NG & NG & NG & & NG & & & & & NG & & & & & & \\
\hline [39] & $\begin{array}{l}\text { PRT, } \\
\text { ESPP }\end{array}$ & 108 & $x$ & NG & & & & & 12 & 10 & NG & & 4 & & & & & 4 & & & & & & \\
\hline [44] & AUS & 68 & 68 & NG & & & & & 8 & 9 & 16 & & 2 & & & & & 2 & & & & & & \\
\hline \multicolumn{25}{|c|}{ Scheme 9 (DHFR, DHPS) } \\
\hline [16] & USA & 37 & 37 & NG & & & & & & & & & & & & & & 4 & & & & & 2 & \\
\hline [32] & FRA & 33 & 33 & NG & & & & & & & & & & & & & & 3 & & & & & 2 & \\
\hline [40] & THA & 29 & 18 & NG & & & & & & & & & & & & & & 3 & & & & & 3 & \\
\hline [71] & USA & 13 & 13 & NG & & & & & & & & & & & & & & 2 & & & & & 2 & \\
\hline [70] & $\mathrm{COL}$ & 98 & 45 & NG & & & & & & & & & & & & & & 4 & & & & & 2 & \\
\hline \multicolumn{25}{|c|}{ Scheme 10 (DHPS, $m t 26 S)$} \\
\hline [17] & USA & 324 & 191 & 14 & & & & & & & & & 4 & & & & & 4 & & & & & & \\
\hline [26] & ESP & 255 & 79 & NG & & & & & & & & & 4 & & & & & 4 & & & & & & \\
\hline [34] & ESP & 50 & 12 & NG & & & & & & & & & 4 & & & & & 1 & & & & & & \\
\hline [35] & USA & 442 & * & NG & & & & & & & & & 4 & & & & & 4 & & & & & & \\
\hline [45] & ESP & 60 & 19 & NG & & & & & & & & & 3 & & & & & 1 & & & & & & \\
\hline [51] & ITA & 67 & $\mathbf{P}$ & NG & & & & & & & & & 4 & & & & & 3 & & & & & & \\
\hline \multicolumn{25}{|c|}{ Scheme 11 (26S, $\beta$-TUB, DHPS, ITS1, $m t 26 S)$} \\
\hline [21] & USA & 22 & 22 & 10 & & & & 2 & 5 & & & & 4 & 2 & & & & 3 & & & & & & \\
\hline \multicolumn{25}{|c|}{ Scheme 12 (26S, $\beta$-TUB, ITS1, ITS2, mt26S) } \\
\hline [22] & ITA & 25 & 18 & 15 & & & & 4 & 6 & 6 & & & 4 & 3 & & & & & & & & & & \\
\hline \multicolumn{25}{|c|}{ Scheme 13 (DHPS, ITS1, ITS2) } \\
\hline [23] & USA & 57 & 37 & NG & & & & & 6 & 7 & NG & & & & & & & 3 & & & & & & \\
\hline [27] & PRT & 43 & 43 & NG & & & & & 15 & 14 & 17 & & & & & & & 2 & & & & & & \\
\hline [36] & ITA & 261 & 174 & NG & & & & & NG & NG & 9 & & & & & & & 3 & & & & & & \\
\hline \multicolumn{25}{|c|}{ Scheme 14 (CYB, DHFR, DHPS) } \\
\hline [24] & JPN & 34 & 34 & NG & & & & & & & & & & & & & & 4 & & & 2 & & 1 & \\
\hline \multicolumn{25}{|c|}{ Scheme 15 (DHPS, ITS1, ITS2, $m t S S U$ ) } \\
\hline [25] & GBR & 2 & 2 & NG & & & & & NG & NG & 2 & & & & & & 1 & 1 & & & & & & \\
\hline \multicolumn{25}{|c|}{ Scheme 16 (DHPS, $m t 26 S, m t S S U)$} \\
\hline [28] & $\begin{array}{l}\text { GBR, } \\
\text { ZWE }\end{array}$ & 51 & 30 & NG & & & & & & & & & 3 & & & & 4 & 2 & & & & & & \\
\hline \multicolumn{25}{|c|}{ Scheme 17 (DHPS, $m t S S U, m t 26 S, S O D)$} \\
\hline [29] & GBR & 16 & 16 & NG & & & & & & & & & NG & & & & NG & NG & & & & NG & & \\
\hline [30] & NG & 76 & 76 & 15 & & & & & & & & & 4 & & & & 4 & 4 & & & & 4 & & \\
\hline
\end{tabular}


Table 1. Cont.

\begin{tabular}{|c|c|c|c|c|c|c|c|c|c|c|c|c|c|c|c|c|c|c|c|c|c|c|c|c|}
\hline \multirow{2}{*}{$\begin{array}{l}\text { Schemes } \\
\text { (Included } \\
\text { Loci) and } \\
\text { Reference }\end{array}$} & \multirow[b]{2}{*}{ Country } & \multirow[b]{2}{*}{$\begin{array}{l}\text { Total \# of } \\
\text { Samples }\end{array}$} & \multirow{2}{*}{$\begin{array}{c}\text { \# of } \\
\text { Samples } \\
\text { Sequenced }\end{array}$} & \multirow{2}{*}{$\begin{array}{c}\text { \# of } \\
\text { Sequence } \\
\text { Types }\end{array}$} & \multicolumn{20}{|c|}{ Genetic Locus } \\
\hline & & & & & $5.8 \mathrm{~S}$ & $18 \mathrm{~S}$ & $23 S$ & $26 \mathrm{~S}$ & ITS1 & ITS2 & ITS $1 / 2$ & $m s g$ & $m t 26 \mathrm{~S}$ & $\beta$-ТUВ & $T S$ & $\begin{array}{l}\text { arom/ } \\
E P S P\end{array}$ & $m t S S U$ & DHPS & UCS & Kex1 & $C Y B$ & $S O D$ & DHRF & TRR1 \\
\hline \multicolumn{25}{|c|}{ Scheme 18 (DHFR, DHPS, ITS1, ITS2) } \\
\hline [37] & PRT & 68 & 68 & NG & & & & & NG & NG & 19 & & & & & & & 4 & & & & & 4 & \\
\hline \multicolumn{25}{|c|}{ Scheme 19 (UCS, Kex1) } \\
\hline [39] & PRT & 87 & 35 & NG & & & & & & & & & & & & & & & 4 & 4 & & & & \\
\hline \multicolumn{25}{|c|}{ Scheme 20 (CYB, DHFR, DHPS, mt26S, SOD) } \\
\hline [46] & PRT & 102 & 78 & NG & & & & & & & & & 9 & & & & & 6 & & & 3 & 6 & 6 & \\
\hline \multicolumn{25}{|c|}{ Scheme 21 ( $\beta$-TUB, CYB, DHFR, DHPS, mt26S, TRR1, TS, SOD) } \\
\hline$[47]$ & PRT & 70 & $\checkmark$ & 48 & & & & & & & & & 5 & 3 & मै & & & 3 & & & 7 & 4 & 3 & मै \\
\hline \multicolumn{25}{|c|}{ Scheme 22 ( $\beta$-TUB, DHPS, ITS1/2, mt26S) } \\
\hline [3] & AUS & 11 & 11 & 2 & & & & & & & 4 & & 2 & 2 & & & & 1 & & & & & & \\
\hline [55] & AUS & 48 & 48 & 4 & & & & & & & 2 & & 2 & 1 & & & & 1 & & & & & & \\
\hline [57] & AUS & 7 & 7 & NG & & & & & & & NG & & NG & NG & & & & NG & & & & & & \\
\hline \multicolumn{25}{|c|}{ Scheme $23(m t 26 S, m t S S U)$} \\
\hline [52] & $\begin{array}{l}\text { FRA, } \\
\text { CUB, } \\
\text { ESP }\end{array}$ & 75 & 75 & NG & & & & & & & & & 5 & & & & 3 & & & & & & & \\
\hline \multicolumn{25}{|c|}{ Scheme 24 (26S, $\beta$-TUB, CYB, DHFR, DHPS, ITS1, $m t 26 S$, SOD) } \\
\hline [5] & FRA & 23 & 23 & NG & & & & 7 & 9 & & & & 4 & 2 & & & & 1 & & & 7 & 3 & 3 & \\
\hline \multicolumn{25}{|c|}{ Scheme 25 (26S, ITS1, ITS2, $m t 26 S)$} \\
\hline [56] & DNK & 22 & 18 & 3 & & & & NG & NG & NG & NG & & NG & & & & & & & & & & & \\
\hline \multicolumn{25}{|c|}{ Scheme 26 (CYB, ITS1, $m t 26 S, S O D)$} \\
\hline$[58]$ & FRA & 37 & 32 & NG & & & & & NG & & & & NG & & & & & & & & NG & NG & & \\
\hline \multicolumn{25}{|c|}{ Scheme 27 ( $\beta$-TUB, CYB, DHFR, $m t 26 S, S O D)$} \\
\hline [59] & BEL & 20 & $20^{\wedge}$ & NG & & & & & NA & & & & 4 & 2 & & & & & & & 4 & 2 & 2 & \\
\hline \multicolumn{25}{|c|}{ Scheme $28(C Y B, m t 26 S, S O D)$} \\
\hline [60] & FRA & 24 & (0) & 14 & & & & & & & & & 6 & & & & & & & & 5 & 3 & & \\
\hline [61] & FRA & 32 & 32 & 18 & & & & & & & & & 22 & & & & & & & & 14 & 4 & & \\
\hline [62] & FRA & 7 & 7 & NG & & & & & & & & & 4 & & & & & & & & 3 & 2 & & \\
\hline [63] & POL & 17 & 0 & 8 & & & & & & & & & 13 & & & & & & & & 6 & 2 & & \\
\hline [66] & FRA & 192 & 35 & 17 & & & & & & & & & 11 & & & & & & & & 5 & 2 & & \\
\hline [67] & $\begin{array}{l}\text { TUR } \\
\text { REU }\end{array}$ & 31 & 26 & 6 & & & & & & & & & 4 & & & & & & & & 5 & 3 & & \\
\hline [68] & $\begin{array}{l}\text { REU, } \\
\text { GUF, } \\
\text { FRA }\end{array}$ & 47 & 47 & 23 & & & & & & & & & 5 & & & & & & & & 9 & 3 & & \\
\hline \multicolumn{25}{|c|}{ Scheme $29(23 S, 26 S, D H P S)$} \\
\hline [64] & BRA & 30 & 30 & 5 & & & 3 & 2 & & & & & & & & & & 1 & & & & & & \\
\hline
\end{tabular}


Table 1. Cont

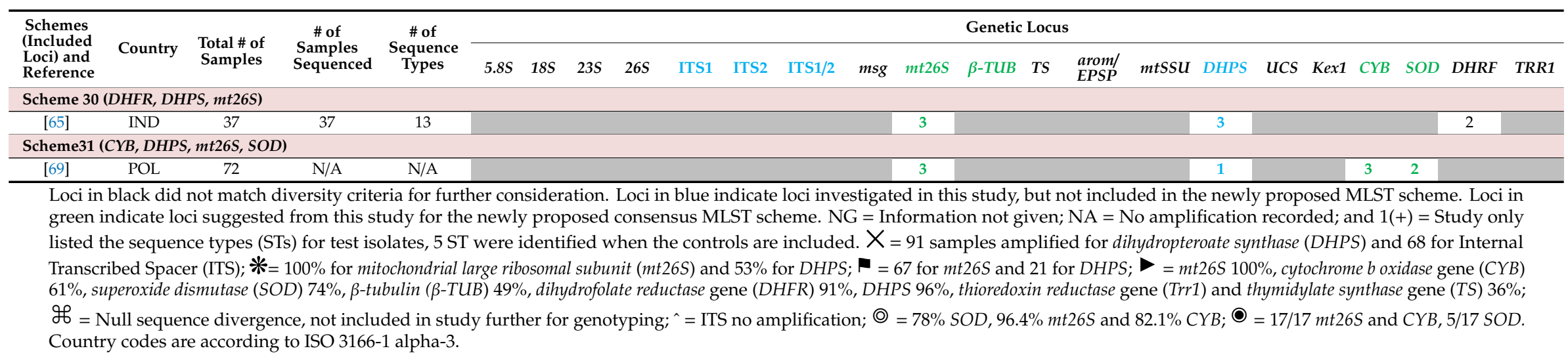


The aim of this study was to establish a consensus MLST scheme for P. jirovecii, taking into account the previously applied loci, to be used globally for P. jirovecii strain typing. Having a global consensus MLST scheme will allow for data exchangeability and comparisons of clinical isolates between laboratories, and the creation of an online world-wide MLST databank for P. jirovecii isolates.

\section{Investigated Loci and Typing Schemes}

To select the most appropriate genetic loci all published loci and respective P. jirovecii genotyping schemes have been evaluated. Since 1994 nineteen genetic loci, representing either single or multi-locus genes, have been used in diverse genotyping analyses of $P$. jirovecii (see Table 1). Due to the limited DNA amount extracted from Pneumocystis positive clinical samples, the loci were rated based on their previous published amplification and sequencing success rates, as well as the diversity revealed per locus and subsequent ability to discriminate between strains.

\subsection{Nuclear rRNA Gene Cluster}

Firstly, the multi-copy nuclear rRNA gene cluster was studied. It consists of five components which have been amplified and sequenced previously, including the $18 \mathrm{~S}$ rDNA gene, the ITS1 region, the $5.8 \mathrm{~S}$ rDNA gene, the ITS2 region and the 265 rDNA gene [6]. While the rDNA genes are highly conserved, the ITS regions show substantial diversity and as such have been used heavily for identification and genotyping of fungi [12]. The ITS1 and ITS2 regions have demonstrated the highest sequence variation among all loci of the rDNA gene cluster, as evident when sequenced as separate loci or in combination of the two regions (including the $5.8 \mathrm{~S}$ gene), using nested-PCR techniques [3]. This has resulted in over 120 unique genotypes for both ITS regions reported and submitted to GenBank [74]. The ITS1 and ITS2 regions were chosen over the other genes in the rDNA gene cluster due to their superior discriminative power.

\subsection{Mitochondrial Genes}

The mitochondrial large ribosomal subunit ( $m t 26 S$ ) gene is involved in basic metabolic functions, with 15 copies within the genome [75]. This locus was selected as it has been considered to be a highly informative genetic marker due to its high variability between isolates, as well as being used as the main target world-wide for $P$. jirovecii detection and identification [76]. Another mitochondrial gene also selected was the cytochrome $b$ gene, which contains approximately six copies per genome [75]. Cytochrome b oxidase gene $(C Y B)$ has been used widely within MLST genotyping of PCP infections and is increasingly commonly used within European hospitals and laboratories [41]. It has a reported high amplifying and sequencing success rate, although it offers a slightly lower variability than the $m+26 S$ locus. Although the mitochondrial small subunit ( $m t S S U$ ) rDNA gene has over twice as many copies than $m t 26 S$ gene, it has considerably reported lower variation over the $m t 26 S$ gene, five unique genotypes compared to 25 [75,77]. Additionally, the locus has only appeared in six publications since 1998, when it was first sequenced for use in MLST. For all those reasons the $m t S S U$ locus was not further considered for the consensus scheme.

\subsection{Nuclear Genes}

Finally, three nuclear genes, $\beta$-tubulin ( $\beta$-TUB), dihydropteroate synthase (DHPS) and superoxide dismutase (SOD) were also selected to be included in the study. $\beta$-TUB, is a single copy gene belonging to the tubulin coding gene family, which has been used for Pneumocystis identification and genotyping since the 1990's and has been published within MLST schemes over 50 times [78]. Additionally, $\beta$-TUB has been used as a target locus for PCP diagnosis and is also part of the International Society of Human and Animal Mycology (ISHAM) MLST database (available online http://mlst.mycologylab.org), the only current MLST database specific to Pneumocystis, hence warranted further investigation [79]. $S O D$ is a single copy gene encoding the production of the enzyme superoxide dismutase, which is commonly used in European studies as an efficient and discriminatory locus for genotyping [29,41]. 
SOD has a lower variation than $\beta$-TUB, but several studies have shown that these loci can be used to differentiate between colonised Pneumocystis (low burden levels) cases and high burden levels, such as in active PCP cases [80].

The final gene selected to be further investigated was DHPS, a highly studied locus due to nonsynonymous, point mutations within codons 55 and 57 . These point mutations offer insights to trimethoprim-sulfamethoxazole (TMP-SMZ) resistance, due to the SMZ region of TMP-SMZ [81]. Drug resistances in P. jirovecii have been suggested by tracking the variations in DHPS, signifying an association between mutations and failure of prophylaxis with sulfa drugs [82]. Due to its high amplification success, along with the ability to give insight to resistance [70], DHPS is a key genetic region for many MLST studies. Despite its extensive use, low levels of genetic variation have been reported, with most studies reporting wild-type sequences being detected [83]. DHPS is also commonly genotyped together with DHFR, the dihydrofolate reductase encoding gene, as both enzymes are part of the folic acid pathway [46]. DHFR is inhibited by trimethoprim, nevertheless, information regarding the occurrence of mutations in DHFR are scarce, and also conflicting [70,82]. Studies have reported varying levels of DHFR mutations, from $2 \%$ to $60 \%$, with no significant trends within global distributions, limiting its validity to be used for discrimination between samples $[16,24,47,84]$. Although this locus is still investigated within PCP treatment research, among the literature it shows slightly lower rates of variation than DHPS, and so would not add any further information when used alongside DHPS within a newly proposed MLST scheme.

The major surface glycoprotein ( $m s g$ ) gene, upstream conserved sequences (USC) genetic regions of the kexin-like serine protease gene (Kex1), thymidylate synthase gene (TS), thioredoxin reductase gene (Trr1), as well as the 5-enolpyruvylshikimate-3 phosphate synthase activity (EPSP) region within the arom gene were not selected for further analysis within this study. These genetic regions displayed an inability to be adequately sequenced, as seen with the msg and USC genes [46,85]. The Trr1, TS, Kex1 and arom gene loci showed a minimal sequence divergence due to being highly conserved housekeeping genes, and, as such, they are not suitable for MLST, as their discriminatory power is too low [13,41].

As a result of this theoretical analysis the following seven genetic loci have been selected for further practical exploration in this study: $\beta$-tubulin gene, cytochrome $b$ oxidase gene, dihydropteroate synthase gene, internal transcribed spacer 1 (ITS1), internal transcribed spacer 2 (ITS2), mitochondrial large ribosomal subunit rRNA gene (mt26S, also known as LSU-mt26S) and superoxide dismutase gene.

\section{Amplification Rate and Variation of Target Loci}

Two cohorts of positive Pneumocystis DNA samples were independently subjected to amplification of the selected loci. The first cohort contained 44 bronchoalveolar lavage (BAL) samples which were PCP positive and were obtained from patients within Chilean hospitals between 2004 and 2014. The second cohort was composed of 23 oropharyngeal washes (OW) and 63 BAL samples from a single centre in Spain, between 2014 and 2018, with 35 positive PCP cases and 51 colonisations.

P. jirovecii PCP was diagnosed either by Grocott-Gomori's methenamine silver stain or direct immunofluorescence (Meridian Bioscience, Inc.) [86]. Samples were processed inside a biosafety cabinet using sterile precautions to avoid contamination. They were homogenised with a sterile pipette and a $200 \mu \mathrm{L}$ aliquot was used for DNA extraction with the QIAamp ${ }^{\circledR}$ DNA Blood Mini kit (Qiagen). P. jirovecii was confirmed via PCR of the mitochondrial large subunit rRNA using the primers pAZ102-E and pAZ102-H [87]. Negative controls were included to monitor for cross-contamination during DNA extraction and purification. An internal control using the human $\beta$-globin gene [79] was used in each sample to detect false negatives. Each sample was run undiluted and as a $1 / 5$ dilution.

The samples were subjected to amplification to assess the effectiveness of the loci in a practical setting, within a range of Pneumocystis samples. To yield higher success rates the PCR primers and the associated amplification protocols were optimised from previously published conditions. Genes were amplified in volumes of $25 \mu \mathrm{L}$ per PCR reaction, using 10X buffer (100 mM Tris-HCL, pH 8.3, $500 \mathrm{mM}$ $\mathrm{KCl}, 15 \mathrm{mM} \mathrm{MgCl}_{2}$ and $0.01 \% w / v$ gelatine), $50 \mathrm{nM} \mathrm{MgCl} 2,2 \mathrm{mM} \mathrm{dNTPs}, 10 \mathrm{ng} / \mu \mathrm{L}$ of each primer, 
$5 \mathrm{U} / \mu \mathrm{L}$ BIOTAQ DNA (Bioline) polymerase and $10 \mu \mathrm{L}$ of genomic DNA. The optimised primers and amplification conditions suggested to be used for the new consensus MLST scheme are shown in Table 2. The amplification conditions which have been used to amplify the loci not included in the new consensus MLST scheme are shown in the Supplementary Table S1.

Table 2. Primer information for the loci of the novel MLST scheme.

\begin{tabular}{|c|c|c|c|c|c|}
\hline Locus & Primer Name & Ref. & Nucleotide Sequence & $\begin{array}{l}\text { Product Size } \\
\text { (Base Pairs) }\end{array}$ & $\begin{array}{c}\text { PCR } \\
\text { Conditions }\end{array}$ \\
\hline \multirow{2}{*}{$\beta-T U B$} & PneumoßTub_F & & 5'-TCATTAGGTGGTGGAACGGG-3' & \multirow{2}{*}{303} & \multirow{4}{*}{$\begin{array}{c}95^{\circ} \mathrm{C} 3 \mathrm{~min} ; \\
45 \text { cycles: } \\
94^{\circ} \mathrm{C} 30 \mathrm{~s} \text {, } \\
60^{\circ} \mathrm{C} 45 \mathrm{~s}, \\
72^{\circ} \mathrm{C} 45 \mathrm{~s} ; \\
72^{\circ} \mathrm{C} 7 \mathrm{~min}\end{array}$} \\
\hline & PneumoßTub_R & & 5'-ATCACCATATCCTGGATCCG-3' & & \\
\hline \multirow{2}{*}{$S O D$} & MnSODFw & \multirow{2}{*}{5} & 5'-GGGTTTAATTAGTCTTTTTAGGCAC-3' & \multirow{2}{*}{602} & \\
\hline & MnSODRw & & 5'-CATGTTCCCACGCATCCTAT-3' & & \\
\hline \multirow{2}{*}{$C Y B$} & CytbFw & \multirow{2}{*}{5} & 5'-CCCAGAATTCTCGTTTGGTCTATT-3' & \multirow{2}{*}{579} & \multirow{4}{*}{$\begin{array}{c}95^{\circ} \mathrm{C} 3 \mathrm{~min} ; \\
45 \text { cycles: } \\
94^{\circ} \mathrm{C} 30 \mathrm{~s} \text {, } \\
55^{\circ} \mathrm{C} 45 \mathrm{~s}, \\
72^{\circ} \mathrm{C} 45 \mathrm{~s} ; \\
72^{\circ} \mathrm{C} 7 \mathrm{~min}\end{array}$} \\
\hline & CytbRw & & 5'-AAGAGGTCTAAAAGCAGAACCTCAA-3' & & \\
\hline \multirow{2}{*}{$m t 26 S$} & PneumoLSU_F & & 5'-TCAGGTCGAACTGGTGTACG-3' & \multirow{2}{*}{297} & \\
\hline & PneumoLSU_R & & 5'-TGTTCCAAGCCCACTTCTT-3' & & \\
\hline
\end{tabular}

Bidirectional sequencing was performed at Macrogen Inc., Seoul, South Korea. The obtained sequences where then assembled and edited using the software package Sequencher ver. 5.4.6 (Gene Codes Corporation). The cleaned-up sequences for each locus were aligned with the program CLUSTALW [88] part of the software MEGA version 10.1 [89] and compared to reference sequences listed in Table 2 and Supplementary Table S1. Allele types were named with respect to previously the published nomenclature [5,41].

The obtained amplification and sequencing success rates varied widely, with the nested PCR of the ITS1/2 locus being the lowest, with $2 \%$ for the Chilean isolates and only $38 \%$ of the Spanish isolates. DHPS and $m t 26 S$ loci had the highest, which amplified $83 \%$ for the Spanish and $100 \%$ for the Chilean isolates and $95 \%$ of the Spanish and $100 \%$ of the Chilean isolates, respectively. Simple PCR of the ITS1 region with the newly designed primers amplified $47 \%$ of the Chilean isolates, although the Spanish were not amplified with this primer. This was then followed by the $\beta$-TUB locus, which amplified $80 \%$ of the Spanish and $78 \%$ of the Chilean isolates, the SOD locus, which amplified $71 \%$ of the Spanish and $91 \%$ of the Chilean isolates, and the CYB locus, which amplified $94 \%$ and $93 \%$ of both Spanish and Chilean isolates, respectively. Average amplification rates of the two cohorts are seen in Figure 1. The Fisher exact test statistic value indicated no significant differences between the individual cohort amplification rates for $\beta-T U B, C Y B$ and $m t 26 S$, and a significant result at $p<0.05$ using the Fisher's exact test [90] for the DHPS, SOD and ITS1/2 loci (for all raw data see Supplementary Table S2).

The genetic loci were then assessed for their ability to discriminate between different strains, as a high variability within individual loci will directly increase the discriminatory value of the consensus scheme. Based on the PCR performance the ITS1/2 and ITS1 loci were not further analysed due to their poor amplification rates. The mitochondrial genes, $m+26 S$ and $C Y B$, were found to have the highest variation, followed by $\beta$-TUB and $S O D$, as judged from the number of unique allele types obtained. The DHPS locus showed the least amount of variation, with the vast majority of alleles corresponding to the wild type and only two variants having been found across the entire collection of samples (Figure 2). A new database of all allele and sequence types has been established at http://mlst.mycologylab.org for the newly proposed consensus P. jirovecii MLST scheme. 


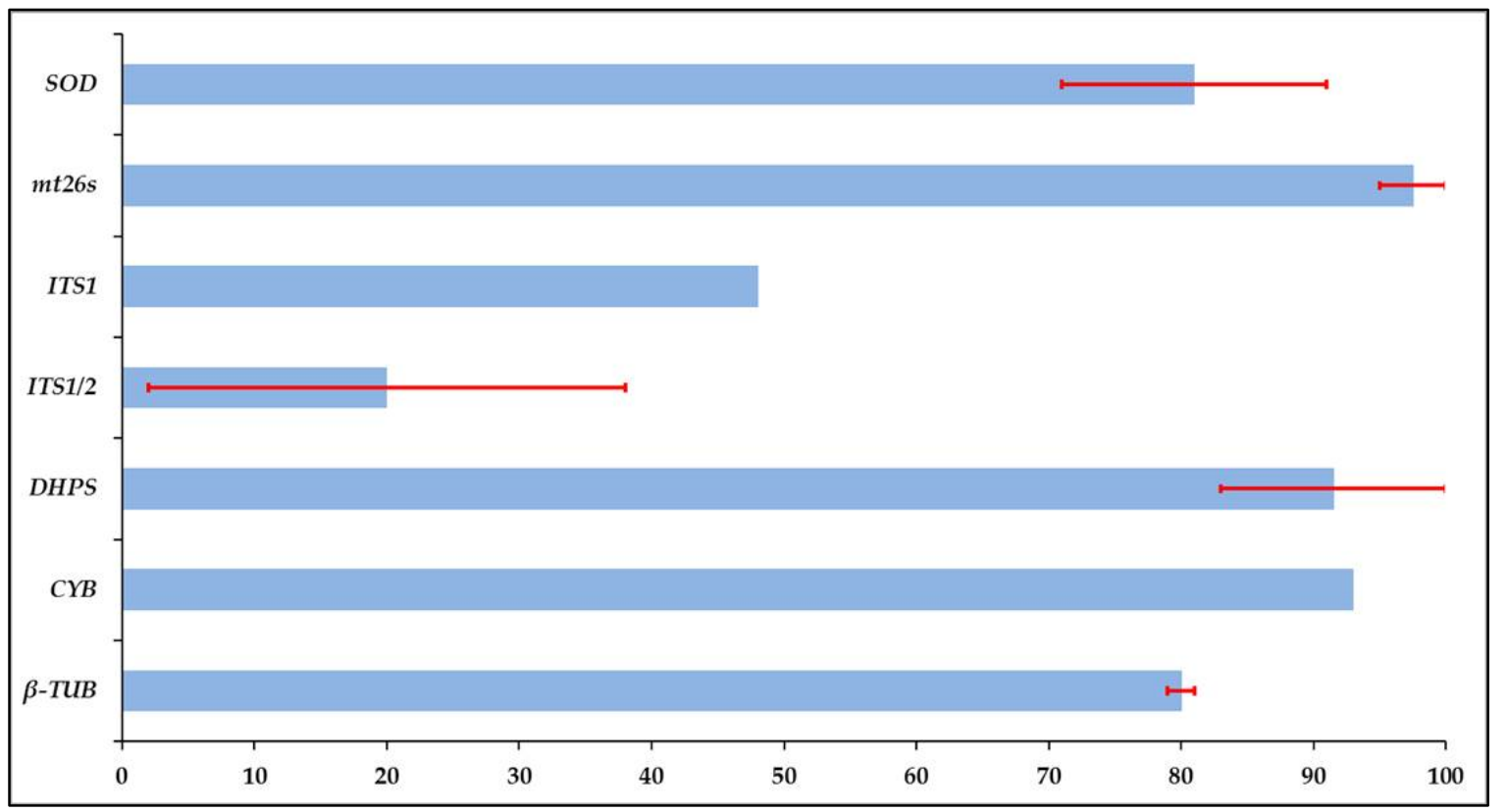

Figure 1. Average amplification and sequencing rates for all targeted genetic loci. Calculations are based on the combined mean amplification and sequencing rates of both cohorts and are expressed as percentages. Error bars indicate the standard deviation.

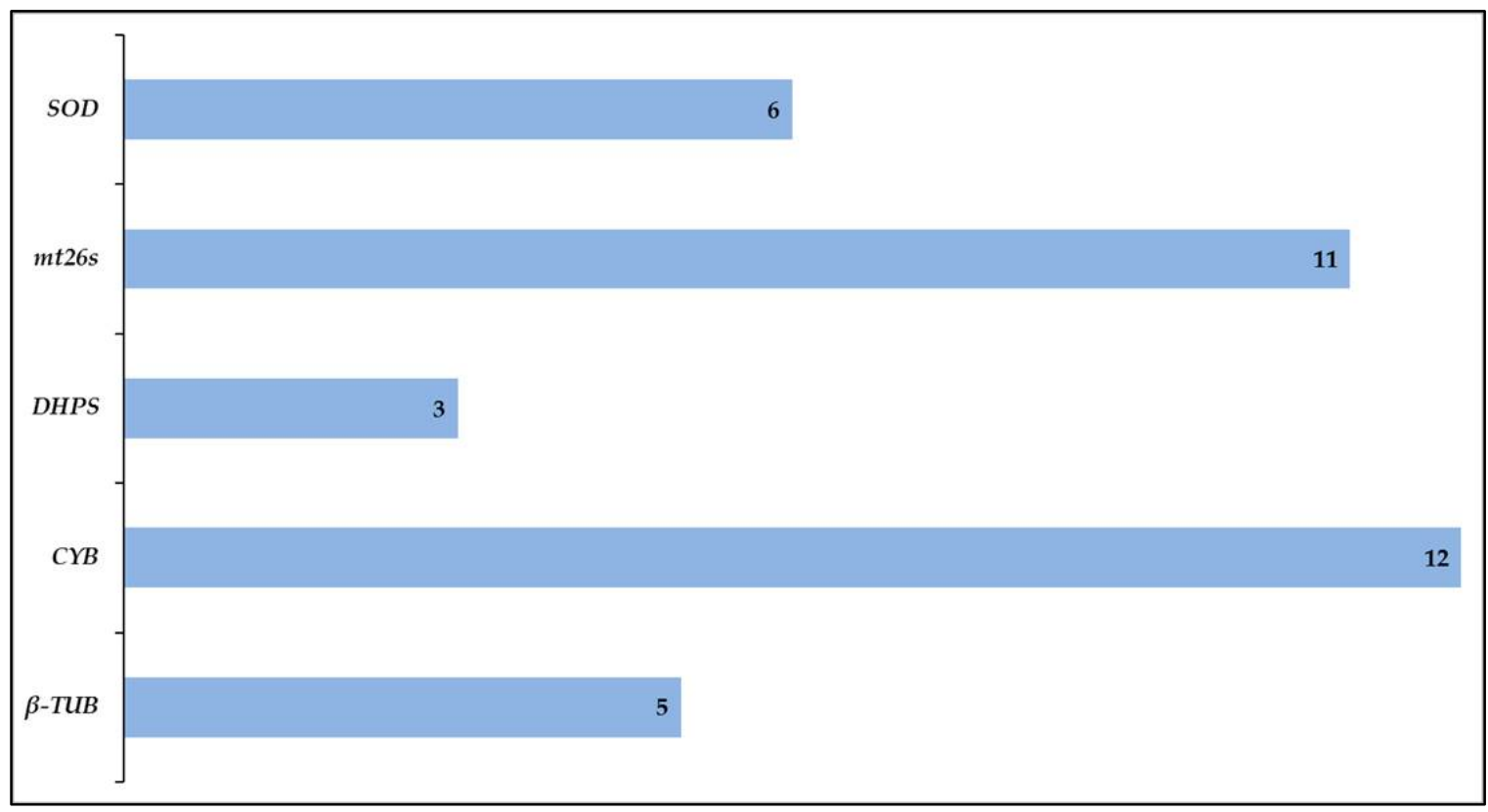

Figure 2. Number of allele types identified amongst all studied isolates.

Based on the above results, showing a superior amplification rate and sequence quality, and high discriminatory power, the following four loci: $\beta-T U B, C Y B, m+26 S$ and SOD were chosen for inclusion in the proposed new consensus $P$. jirovecii MLST scheme.

\section{Case Study: Assessing the Ability to Discriminate between Clinical Isolates}

To access the efficiency to identify related and to differentiate between unrelated $P$. jirovecii isolates these four loci were then used to genotype six positive Pneumocystis samples representing a potential cluster (two epidemiologically linked isolates) and four independent cases. Allelic profiles were assigned to each sample using the newly developed MLST database available online at 
http://mlst.mycologylab.org (Table 3) confirming the suspected to be related isolates and successfully separated all four suspected unrelated isolates (Figure 3). The two suspected related isolates showed identical MLST profiles corresponding both to the ST21. The four suspected unrelated isolates had all unique MLST profiles, ST2, ST7, ST42 and ST44, and where also different from the two related isolates (Table 1 and Figure 3). Cross contamination between samples was ruled out as samples were analysed on different days and results were checked by resequencing a second aliquot.

Table 3. Allele types and sequence types of two related and four unrelated P. jirovecii isolates. Colours indicate the different allele types per genetic locus.

\begin{tabular}{cccccccc}
\hline $\begin{array}{c}\text { Strain } \\
\text { Number }\end{array}$ & $\begin{array}{c}\text { Country of } \\
\text { Origin }\end{array}$ & $\begin{array}{c}\text { Date of } \\
\text { Sample }\end{array}$ & $\boldsymbol{\beta}$-TUB & CYB & mt26S & SOD & $\begin{array}{c}\text { Sequence } \\
\text { Type }\end{array}$ \\
\hline HVH21 & Spain & Jan 2015 & 2 & 1 & 3 & 1 & ST21 \\
\hline HVH22 & Spain & Jan 2015 & 2 & 1 & 3 & 1 & ST21 \\
\hline Case 63 & Australia & Dec 2016 & 1 & 3 & 1 & 4 & ST42 \\
\hline Case 71 & New Zealand & May 2017 & 4 & 2 & 2 & 4 & ST44 \\
\hline 1794 & Chile & Feb 2011 & 2 & 5 & 4 & 1 & ST7 \\
\hline 2165 & Chile & Oct 2014 & 2 & 2 & 4 & 5 & ST2 \\
\hline
\end{tabular}

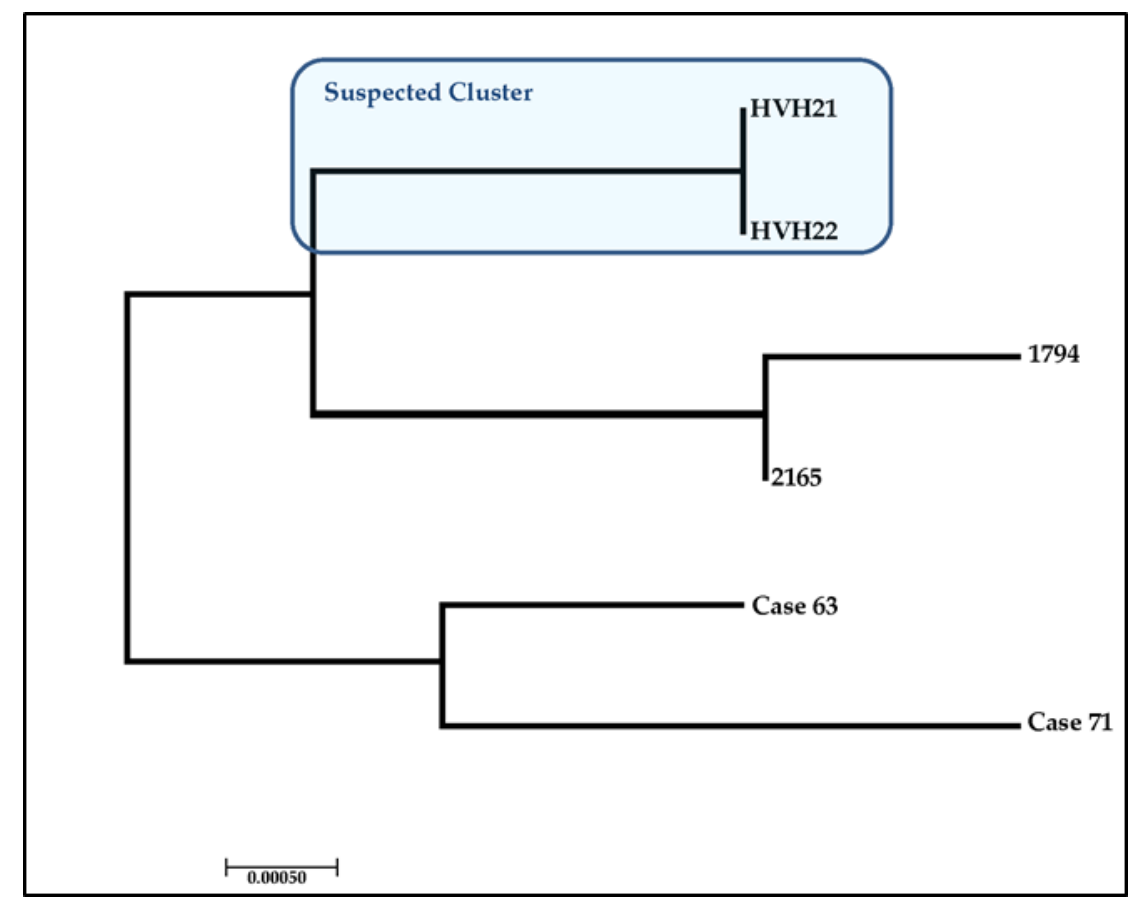

Figure 3. Phylogenetic tree of six P. jirovecii isolates (patients from Table 3) used in the case study to show the discriminatory power of the new consensus P. jirovecii MLST scheme, obtained by maximum likelihood analysis with the general time reversible (GTR) model with RaxML (version 7.2.8) using RaxmlGUI 1.1 [91], part of the software package MEGA ver. 7.0 [92].

\section{Discussion}

Genotyping of $P$. jirovecii is vital for the advancement of understanding of the biology, pathogenesis, epidemiology, prophylaxis and treatment regimen of this human pathogen, but more specifically it is vital to help manage, contain and prevent nosocomial clusters. With a rise of nosocomial outbreaks since the early 2000s, hospitals have recorded catastrophic consequences of PCP outbreaks, with up to $83 \%$ of reported outbreaks being described within organ transplant wards, as well as in patients with haematological malignancies and connective tissue diseases [93]. Large graft failure and over 
$50 \%$ casualties in wards has been reported from single outbreaks, demonstrating the severity of this underestimated disease [94].

An effective way to investigate epidemiological links is through the creation of transmission maps by combining molecular typing along with studying patient encounters and interactions within the hospital [5]. However, the fact that there are currently 19 genetic regions being used in 31 different typing schemes for $P$. jirovecii limits effective epidemiological studies. The lack of a consensus scheme directly inhibits the ability to compare results, polymorphic strains, and epidemiological data between research centres, and hinders the possibility of establishing global databases and conducting large-scale population studies.

To overcome these limitations, a comprehensive study of all genes and schemes was herein undertaken to assess which loci and which combination of loci would allow for the development of the most practical, efficient and discriminatory scheme. Previous studies looked at the performance of various schemes to suggest a possible consensus scheme, but none have since been formally brought forward as a suggested universal scheme [3]. Maitte et al. 2013 [5], in their review suggested that an eight loci scheme provided the most powerful genotyping results, but this is only possible theoretically due to the limited amount of DNA available from $P$. jirovecii in clinical samples. There are no reliable methods to culture the P. jirovecii in vitro, therefore the DNA amount which comes directly from clinical samples is limited [7]. The volume is then further limited depending on the fungal load as well as the source of the specimen [95]. HIV positive patients have high fungal loads, whilst colonised carriers and HIV-negative PCP patients carry lower levels [96]. Bronchoalveolar lavage specimens are the preferred sample, yielding the highest sensitivity due to a greater fungal concentration and also yielding an acceptable negative predictive value [97]. The same studies have shown that the less invasive method, induced sputum (IS), showed comparable levels of fungal burden as BAL, followed by oropharyngeal washes, and then to a lesser extent nasopharyngeal aspirates, and nasal swabs [93,95]. It is therefore vital to have a typing system, consisting of as few genetic loci as possible, but being able to detect and amplify specimens with low levels of fungal burden, as this is often the first limiting step when undergoing Pneumocystis genotyping analysis.

On the other side, having too few loci also poses a problem, since lowering the number of loci in a scheme then decreases the discriminatory power and the ability to distinguish between closely related strains. Studies have shown that often schemes with less than three loci do not have enough variation to accurately genotype, as such the Hunter $(\mathrm{H})$-index has been used in multiple studies to demonstrate the discriminatory power of a scheme [5]. The H-index should not be the only determining factor of an effective scheme as it is highly variable depending on the number of isolates being tested, but it has been a useful tool to help predict the estimated discriminatory power of a scheme [98]. A H-index of 0.95 or higher is considered a suitable cut-off benchmark for MLST schemes, and the review by Maitte et al. 2013 [5] showed that there were no genetic regions which could work individually or paired with another, that would meet this cut-off [19]. As seen in Table 1, there are multiple schemes used in genotyping which are comprised of only two loci, casting a shadow of doubt on their results and generated epidemiological data of these studies, further reinforcing the need for standardisation amongst the Pneumocystis scientific community.

As a result, eight genetic regions were explored in this study as potential loci which could be included in a global consensus scheme, by analysing their amplification ability and demonstrating their discriminatory power. The whole ITS region is widely reported to have the most variability within P. jirovecii and is highly useful when identifying and genotyping other invasive fungi [74]. Unfortunately, it also has been reported to have a high amplification failure when applied to P. jirovecii [59], which was also evident in the current study, as ITS1 alone and ITS1/2 regions showed to have the lowest amplification capability, unable to amplify and successfully sequence more than $50 \%$ of the studied isolates for either primer set. Studies have reported that using nested-PCR instead of conventional, single-round PCR can help to overcome the lack of amplification for the ITS region [3,99]. This was not the case in the herein reported study, as the nested-PCR protocol for the ITS1/2 regions performed 
considerably worse than single round PCR for the ITS1 region within the Chilean cohort. Due to the lack in amplification success, both in this study and others, no loci from the nuclear rRNA gene cluster were further considered for involvement in a new consensus MLST scheme.

Conversely to the ITS region, DHPS amplification was highly successful achieving a global $91.5 \%$ amplification success, with minor variations that can be attributed to differences associated to the spectrum of clinical settings covered, ranging from colonisations to infections. DHPS is heavily used among P. jirovecii genotyping and has been consistently used since the late 1990s in diverse schemes. Despite this, within the reported literature, DHPS does not reveal much variation, as such most often wild-types are reported, carrying no informative data to discriminate between strains, showing a $\mathrm{H}$-index of 0 in previous studies $[5,100,101]$. DHPS has demonstrated effectiveness when exploring TMP-SMZ resistance, by showing mutations at the 55 and 57 codons [102]. Population studies using the DHPS locus have effectively been able to track additional sulfa pressure in geographical regions with or without widespread use, and as such accurately predict or identify sulfamethoxazole resistance within these regions $[103,104]$. In this study, only two allele types have been identified, with most of the isolates showing the wildtype, showing regional differences in the distribution of wildtype and allelic variants, subject to further studies. The mutations can be used to give an insight in the widespread use of TMP-SMZ, and for a further comparison between other geographical locations heavily using SMZ but not showing resistance within the community. From a genotyping perspective, the DHPS locus, however, does not offer enough variation to be considered as a useful locus within a consensus scheme, and was therefore no longer considered within this study. Despite its drawback to sufficiently discriminate between isolates, researchers should maintain DHPS typing for assessing prophylaxis and treatment resistance within populations, and DHPS can further be explored for its use as an identifying genetic target in PCP diagnosis due to its successful amplification properties.

Two schemes which use the loci explored in this study and are predominant in the literature are: The official scheme promoted by ISHAM [3], consisting of $\beta$-TUB, DHPS, ITS1 or ITS1/2 and $m t 26 S$; and a French scheme first proposed by Maitte et al. 2013 [5], consisting of $C Y B, m t 26 S$ and $S O D$. The ISHAM scheme is highly discriminatory, when applied to both herein studied cohorts it resulted in an $\mathrm{H}$ index of $>0.98$. for both cohorts. The $\mathrm{H}$ index was calculated as per Hunder et al. 1988 [98]. Due to different ITS regions explored, ITS1 in the Chilean cohort was able to identify 23 unique sequence types using this scheme, and ITS1/2 in the Spanish cohort attained 14 sequence types. The Maitte et al. 2013 [5] scheme has been reported to have a H-index above 0.95, but this index fell below the threshold when larger sample sizes were considered. H indexes $\leq 0.945$ were attained when herein applied to the Chilean and Spanish cohorts, with 33 unique ST detected.

Since the DHPS and ITS are not appropriate loci to be used in MLST schemes, the ISHAM scheme could not be promoted for universal application, and neither could the Maitte et al. 2013 [5] scheme, due to inconsistencies with sub-optimal levels of discrimination. $\beta$-TUB, CYB, $m t 26 S$ and $S O D$ genetic regions were all individually effective in amplification, but unable to individually discriminate effectively enough, therefore a new consensus MLST scheme comprising of these four loci is herein proposed.

When applied to both cohorts, the new MLST scheme was able to discover a total of 38 unique sequence types, with a combined H-index of 0.975 , which is well above the discriminatory cut-off margin for any useful MLST typing scheme.

As this new MLST scheme had not been previously used, the next step was to explore the effectiveness of the scheme to successfully individual P. jirovecii isolates. The new MLST scheme was applied to two suspected epidemiologically linked isolates and four isolates for which clinical metadata suggested no relationship, to determine whether it would be discriminatory enough to distinguish the isolates appropriately. The MLST analysis revealed a distinct cluster, showing the genotype ST1, consisting of two patients, named HVH21 and HVH22. The identical sequences of patient HVH21 and $\mathrm{HVH} 22$ confirmed the suspected fact of relatedness, which is based on the metadata of the patients, which suggested a possible nosocomial cross-transmission. The cluster involved an HIV positive 
colonised patient and a colonised lung transplant recipient, both with a positive BAL, obtained three days apart. Transmission could have taken place at the radiology department, which both had attended on the same day. The other four epidemiologically unlinked isolates were successfully separated from the cluster and revealed each a unique sequence type, ST7, ST13, SR18 and ST21, which was expected as they were obtained from patients from different geographic regions, including Australia, New Zealand and Chile. With the Chilean isolates originating from patients from different Chilean health centres (public and private) three years apart. As such, the newly established consensus MLST scheme has demonstrated its ability to discriminate appropriately between $P$. jirovecii isolates, making it a powerful tool to identify identical strains in settings with many associated cases, such as in an outbreak situation. However, the obtained typing data should always be complemented with a clinical history as good as possible to trace back the origin.

The herein obtained results demonstrated that the new MLST scheme consisting of $\beta-T U B, C Y B$, $m t 26 S$ and SOD (Table 2) has a much higher amplification rate and an efficient discriminatory power to be applied for genotyping of $P$. jirovecii isolates from clinical samples with high and low fungal burdens, including disease causing and colonising isolates.

Promoting this novel MLST scheme as a global consensus scheme will for the first time standardise MLST for the human pathogen P. jirovecii and set up the basis of a substantial improvement in understanding the relationship between clinical $P$. jirovecii isolates. This will allow real-time genotyping of current infected patients and suspected colonised carriers to be now undertaken to improve the understanding of transmissions and the effect colonised carriers have on nosocomial spreads. Further, this will influence public health approaches for preventing nosocomial infections, in especially high-risk patients, such as those recovering from organ transplantation in close approximate in hospital wards.

Since there is no current database, outside of the ISHAM MLST database [3], available online at http://mlst.mycologylab.org/, it is difficult to find all currently published allele types and the lack of standardisation across global centres often cause confusion, even when attempting to compare allele types of a certain locus. The new global database, also placed at http://mlst.mycologylab.org, established herein will improve the nomenclature of allele types and sequence types and makes it easier for researchers and clinician to have one source of information for all genotyping data. The herein standardised MLST scheme will enable the establishment of such a global database, which can be used by all clinical diagnostic and research centres to deposit metadata and sequences, allowing to compare global specimens, something which was not previously possible.

\section{Conclusions}

In conclusion, this study demonstrates the importance of a consensus MLST scheme for P. jirovecii genotyping and the formation of a global database in expanding the understanding of this important human pathogenic fungus. Based on the previous schemes and the evidence in this study, a novel MLST for the genotyping of $P$. jirovecii, consisting of four genetic regions: $\beta-T U B, C Y B, m t 26 S$ and $S O D$ is proposed. This combination of loci maximises the likelihood for amplification and adequate discrimination of isolates over previously used schemes and will aid hospitals in drawing conclusions about interhuman transmission between patients, and hopefully minimise or early detect nosocomial outbreaks.

Supplementary Materials: The following are available online at http://www.mdpi.com/2309-608X/6/4/259/s1, Table S1: Primer information for the initially tested but finally not selected loci. Table S2: Amplification rates of all tested loci for both cohorts.

Author Contributions: Conceptualization, W.M. and M.T.M.-G.; methodology, L.P., L.G., L.I. and C.A.P.; validation, L.P. and L.G.; formal analysis, L.P., L.G., and M.G.-M.; investigation, L.P. and L.G.; resources, W.M. and M.T.M.-G.; data curation, L.P., L.G. and A.K.; writing—original draft preparation, L.P., L.G., M.T.M.-G. and W.M.; writing-review and editing, L.P., L.G., M.G.-M., L.I., A.K., C.A.P., S.L.V., M.T.M.-G. and W.M.; visualization, L.P.; supervision, W.M. and M.T.M.-G.; project administration, W.M.; funding acquisition, W.M., S.L.V. and M.T.M.-G. All authors have read and agreed to the published version of the manuscript. 
Funding: This study was supported by a National Health and Medical Research Council of Australia (NH\&MRC) grant [no. APP1121936] to W.M., by a National Fund for Science and Technology from Chile (Fondecyt-ANID) grant [no. 1140412] to S.L.V.

Acknowledgments: The authors thank all clinicians and clinical microbiologists who submitted clinical samples to the study.

Conflicts of Interest: The authors declare no conflict of interest.

\section{References}

1. Meenakshi, K.; Gowtham, R.R.; Usha, K. Pneumocystis jirovecii Pneumonia: A Revisit to the Old Malady. J. Clin. Diagn. Res. 2019, 13, DE01-DE08. [CrossRef]

2. Morris, A.; Lundgren, J.D.; Masur, H.; Walzer, P.D.; Hanson, D.L.; Frederick, T.; Huang, L.; Beard, C.B.; Kaplan, J.E. Current epidemiology of Pneumocystis pneumonia. Emerg. Infect. Dis. 2004, 10, 1713-1720. [CrossRef] [PubMed]

3. Phipps, L.M.; Chen, S.C.-A.; Kable, K.; Halliday, C.L.; Firacative, C.; Meyer, W.; Wong, G.; Nankivell, B.J. Nosocomial Pneumocystis jirovecii pneumonia: Lessons from a cluster in kidney transplant recipients. Transplantation 2011, 92, 1327-1334. [CrossRef] [PubMed]

4. Sokulska, M.; Kicia, M.; Wesołowska, M.; Hendrich, A.B. Pneumocystis jirovecii-From a commensal to pathogen: Clinical and diagnostic review. Parasitol. Res. 2015, 114, 3577-3585. [CrossRef] [PubMed]

5. Maitte, C.; Leterrier, M.; Le Pape, P.; Miegeville, M.; Morio, F. Multilocus sequence typing of Pneumocystis jirovecii from clinical samples: How many and which loci should be used? J. Clin. Microbiol. 2013, 51, 2843-2849. [CrossRef]

6. Lu, J.-J.; Bartlett, M.S.; Shaw, M.M.; Queener, S.F.; Smith, J.W.; Ortiz-Rivera, M.; Leibowitz, M.J.; Lee, C.-H. Typing of Pneumocystis carinii strains that infect humans based on nucleotide sequence variations of internal transcribed spacers of rRNA genes. J. Clin. Microbiol. 1994, 32, 2904-2912. [CrossRef]

7. Tsolaki, A.G.; Miller, R.F.; Underwood, A.P.; Banerji, S.; Wakefield, A.E. Genetic diversity at the internal transcribed spacer regions of the rRNA operon among isolates of Pneumocystis carinii from AIDS patients with recurrent pneumonia. J. Infect. Dis. 1996, 174, 141-156. [CrossRef]

8. Keely, S.P.; Stringer, J.R. Multi-locus genotype switching in Pneumocystis carinii sp. f. hominis: Evidence for reinfection. J. Eukaryot. Microbiol. 1996, 43, 50S.

9. Hauser, P.M.; Francioli, P.; Bille, J.; Telenti, A.; Blanc, D.S. Typing of Pneumocystis carinii f. sp. hominis by single-strand conformation polymorphism of four genomic regions. J. Clin. Microbiol. 1997, 35, 3086-3091.

10. Keely, S.P.; Stringer, J.R. Sequences of Pneumocystis carinii f. sp. hominis strains associated with recurrent pneumonia vary at multiple loci. J. Clin. Microbiol. 1997, 35, 2745-2747.

11. Olsson, M.; Lidman, C.; Latouche, S.; Björkman, A.; Roux, P.; Linder, E.; Wahlgren, M. Identification of Pneumocystis carinii f. sp. hominis gene sequences in filtered air in hospital environments. J. Clin. Microbiol. 1998, 36, 1737-1740. [PubMed]

12. Tsolaki, S.; Ortona, E.; Mazars, E.; Margutti, P.; Tamburrini, E.; Siracusano, A.; Guyot, K.; Nigou, M.; Roux, P. Biodiversity of Pneumocystis carinii hominis: Typing with different DNA regions. J. Clin. Microbiol. 1997, 35, 383-387.

13. Tsolaki, A.G.; Beckers, P.; Wakefield, A.E. Pre-AIDS era isolates of Pneumocystis carinii f. sp. hominis: High genotypic similarity with contemporary isolates. J. Clin. Microbiol. 1998, 36, 90-93. [PubMed]

14. Lee, C.-H.; Helweg-Larsen, J.; Tang, X.; Jin, S.; Li, B.; Bartlett, M.S.; Lu, J.-J.; Lundgren, B.; Lundgren, J.D.; Olsson, M. Update on Pneumocystis carinii f. sp. hominis typing based on nucleotide sequence variations in internal transcribed spacer regions of rRNA genes. J. Clin. Microbiol. 1998, 36, 734-741. [PubMed]

15. Santos, L.D.; Lacube, P.; Latouche, S.; Kac, G.; Mayaud, C.; Marteau, M.; Poirot, J.L.; Maury, E.; Guillot, J.; Roux, P. Contribution of Dihydropteroate synthase gene typing for Pneumocystis carinii f. sp. hominis epidemiology. J. Eukaryot. Microbiol. 1999, 46, 133 S.

16. Ma, L.; Borio, L.; Masur, H.; Kovacs, J.A. Pneumocystis carinii dihydropteroate synthase but not dihydrofolate reductase gene mutations correlate with prior trimethoprim-sulfamethoxazole or dapsone use. J. Infect. Dis. 1999, 180, 1969-1978. [CrossRef] 
17. Beard, C.B.; Carter, J.L.; Keely, S.P.; Huang, L.; Pieniazek, N.J.; Moura, I.N.; Roberts, J.M.; Hightower, A.W.; Bens, M.S.; Freeman, A.R. Genetic variation in Pneumocystis carinii isolates from different geographic regions: Implications for transmission. Emerg. Infect. Dis. 2000, 6, 265-272. [CrossRef]

18. Hosoya, N.; Takahashi, T.; Wada, M.; Endo, T.; Nakamura, T.; Sakashita, H.; Kimura, K.; Ohnishi, K.; Nakamura, Y.; Mizuochi, T. Genotyping of Pneumocystis carinii f. sp. hominis isolates in Japan based on nucleotide sequence variations in internal transcribed spacer regions of rRNA genes. Microbiol. Immunol. 2000, 44, 591-596.

19. Hauser, P.M.; Blanc, D.S.; Sudre, P.; Manoloff, E.S.; Nahimana, A.; Bille, J.; Weber, R.; Francioli, P. Genetic diversity of Pneumocystis carinii in HIV-positive and-negative patients as revealed by PCR-SSCP typing. Aids 2001, 15, 461-466. [CrossRef]

20. Hauser, P.M.; Sudre, P.; Nahimana, A.; Francioli, P.; Group, S. Prophylaxis failure is associated with a specific Pneumocystis carinii genotype. Clin. Infect. Dis. 2001, 33, 1080-1082. [CrossRef]

21. Ma, L.; Kovacs, J.A. Genetic analysis of multiple loci suggests that mutations in the Pneumocystis carinii f. sp. hominis dihydropteroate synthase gene arose independently in multiple strains. Antimicrob. Agents Chemother. 2001, 45, 3213-3215. [CrossRef]

22. Volpe, G.; Sbaiz, L.; Avanzini, C.; Caramello, P.; Savoia, D. Genetic diversity of Pneumocystis carinii isolated from human immunodeficiency virus-positive patients in Turin, Italy. J. Clin. Microbiol. 2001, 39, 2995-2998. [CrossRef] [PubMed]

23. Meshnick, S.R.; Hossler, P.A.; Enger, K.S.; Kazanjian, P.; Rest, J.S.; Mindell, D.; Li, B.; Lee, C.; Nimri, L.F.; Carter, J.L. Distribution of DHPS mutations among ITS subtypes of P. carinii f. sp. hominis. J. Eukaryot. Microbiol. 2001. [CrossRef]

24. Takahashi, T.; Kanda, T.; Iwamoto, A. Genetic diversity of drug targets including Dihydropteroate synthase, Dihydrofolate reductase and Cytochrome b, in Pneumocystis carinii f. sp. hominis isolates in Japan. Res. Commun. Mol. Pathol. Pharmacol. 2002, 112, 159-176. [PubMed]

25. Miller, R.F.; Ambrose, H.E.; Novelli, V.; Wakefield, A.E. Probable mother-to-infant transmission of Pneumocystis carinii f. sp. hominis infection. J. Clin. Microbiol. 2002, 40, 1555-1557.

26. Montes-Cano, M.A.; De la Horra, C.; Martin-Juan, J.; Varela, J.M.; Torronteras, R.; Respaldiza, N.; Medrano, F.J.; Calderón, E.J. Pneumocystis jiroveci genotypes in the Spanish population. Clin. Infect. Dis. 2004, 39, 123-128. [CrossRef]

27. Matos, O.; Lee, C.-H.; Jin, S.; Li, B.; Costa, M.C.; Gonçalves, L.; Antunes, F. Pneumocystis jirovecii in Portuguese immunocompromised patients: Association of specific ITS genotypes with treatment failure, bad clinical outcome and childhood. Infect. Genet. Evol. 2003, 3, 281-285. [CrossRef]

28. Miller, R.F.; Lindley, A.R.; Ambrose, H.E.; Malin, A.S.; Wakefield, A.E. Genotypes of Pneumocystis jirovecii isolates obtained in Harare, Zimbabwe, and London, United Kingdom. Antimicrob. Agents Chemother. 2003, 47, 3979-3981. [CrossRef] [PubMed]

29. Wakefield, A.E.; Lindley, A.R.; Ambrose, H.E.; Denis, C.-M.; Miller, R.F. Limited asymptomatic carriage of Pneumocystis jirovecii in human immunodeficiency virus-infected patients. J. Infect. Dis. 2003, 187, 901-908. [CrossRef]

30. Miller, R.F.; Lindley, A.R.; Ambrose, H.E.; Aliouat-Denis, C.M.; Wakefield, A.E. Multilocus Genotyping of Pneumocystis jirovecii from Adult HIV-Infected Patients with Pneumocystis Pneumonia. J. Eukaryot. Microbiol. 2003, 50, 654-655. [CrossRef] [PubMed]

31. Robberts, F.J.L.; Liebowitz, L.D.; Chalkley, L.J. Genotyping and coalescent phylogenetic analysis of Pneumocystis jirovecii from South Africa. J. Clin. Microbiol. 2004, 42, 1505-1510. [CrossRef] [PubMed]

32. Nahimana, A.; Rabodonirina, M.; Helweg-Larsen, J.; Meneau, I.; Francioli, P.; Bille, J.; Hauser, P.M. Sulfa resistance and Dihydropteroate synthase mutants in recurrent Pneumocystis carinii pneumonia. Emerg. Infect. Dis. 2003, 9, 864-867. [CrossRef] [PubMed]

33. Höcker, B.; Wendt, C.; Nahimana, A.; Tönshoff, B.; Hauser, P.M. Molecular evidence of Pneumocystis transmission in pediatric transplant unit. Emerg. Infect. Dis. 2005, 11, 330-332. [CrossRef] [PubMed]

34. Medrano, F.J.; Montes-Cano, M.; Conde, M.; De La Horra, C.; Respaldiza, N.; Gasch, A.; Perez-Lozano, M.J.; Varela, J.M.; Calderon, E.J. Pneumocystis jirovecii in general population. Emerg. Infect. Dis. 2005, 11, 245-250. [CrossRef] 
35. Beard, C.B.; Fox, M.R.; Lawrence, G.G.; Guarner, J.; Hanzlick, R.L.; Huang, L.; del Rio, C.; Rimland, D.; Duchin, J.S.; Colley, D.G. Genetic differences in Pneumocystis isolates recovered from immunocompetent infants and from adults with AIDS: Epidemiological implications. J. Infect. Dis. 2005, 192, 1815-1818. [CrossRef]

36. Valerio, A.; Tronconi, E.; Mazza, F.; Cargnel, A.; Fantoni, G.; Atzori, C. DHPS -Mutated Isolates of Pneumocystis jirovecii from HIV-Infected Individuals: Analysis of Related ITS Genotypes. J. Eukaryot. Microbiol. 2006, 53, S108-S109. [CrossRef]

37. Costa, M.C.; Esteves, F.; Antunes, F.; Matos, O. Multilocus genotyping of Pneumocystis jirovecii in immunocompromised patients: Preliminary results. J. Eukaryot. Microbiol. 2006, 53, S104-S105. [CrossRef]

38. Gupta, R.; Mirdha, B.R.; Guleria, R.; Mohan, A.; Kabra, S.K.; Kumar, L.; Agarwal, S.K.; Luthra, K. Use of different primer directed sequence amplification by polymerase chain reaction for identification of Pneumocystis jirovecii in clinical samples. Indian J. Chest Dis. Allied Sci. 2008, 50, 321-327.

39. Esteves, F.; Montes-Cano, M.A.; De La Horra, C.; Costa, M.C.; Calderón, E.J.; Antunes, F.; Matos, O. Pneumocystis jirovecii multilocus genotyping profiles in patients from Portugal and Spain. Clin. Microbiol. Infect. 2008, 14, 356-362. [CrossRef]

40. Siripattanapipong, S.; Leelayoova, S.; Mungthin, M.; Worapong, J.; Tan-Ariya, P. Study of DHPS and DHFR genes of Pneumocystis jirovecii in Thai HIV-infected patients. Med. Mycol. 2008, 46, 389-392. [CrossRef]

41. Esteves, F.; Gaspar, J.; Tavares, A.; Moser, I.; Antunes, F.; Mansinho, K.; Matos, O. Population structure of Pneumocystis jirovecii isolated from immunodeficiency virus-positive patients. Infect. Genet. Evol. 2010, 10, 192-199. [CrossRef] [PubMed]

42. Schmoldt, S.; Schuhegger, R.; Wendler, T.; Huber, I.; Söllner, H.; Hogardt, M.; Arbogast, H.; Heesemann, J.; Bader, L.; Sing, A. Molecular evidence of nosocomial Pneumocystis jirovecii transmission among 16 patients after kidney transplantation. J. Clin. Microbiol. 2008, 46, 966-971. [CrossRef]

43. Gianella, S.; Haeberli, L.; Joos, B.; Ledergerber, B.; Wuethrich, R.-P.; Weber, R.; Kuster, H.; Hauser, P.-M.; Fehr, T.; Mueller, N.J. Molecular evidence of interhuman transmission in an outbreak of Pneumocystis jirovecii pneumonia in renal transplant recipients. Transpl. Infect. Dis. 2010, 12, 1-10. [CrossRef]

44. van Hal, S.J.; Gilgado, F.; Doyle, T.; Barratt, J.; Stark, D.; Meyer, W.; Harkness, J. Clinical significance and phylogenetic relationship of novel Australian Pneumocystis jirovecii genotypes. J. Clin. Microbiol. 2009, 47, 1818-1823. [CrossRef] [PubMed]

45. Montes-Cano, M.A.; Chabe, M.; Fontillon-Alberdi, M.; de la Horra, C.; Respaldiza, N.; Medrano, F.J.; Varela, J.M.; Dei-Cas, E.; Calderon, E.J. Vertical transmission of Pneumocystis jirovecii in humans. Emerg. Infect. Dis. 2009, 15, 125-127. [CrossRef]

46. Esteves, F.; Tavares, A.; Costa, M.C.; Gaspar, J.; Antunes, F.; Matos, O. Genetic characterization of the UCS and Kex1 loci of Pneumocystis jirovecii. Eur. J. Clin. Microbiol. Infect. Dis. 2009, 28, 175-178. [CrossRef] [PubMed]

47. Esteves, F.; Gaspar, J.; Marques, T.; Leite, R.; Antunes, F.; Mansinho, K.; Matos, O. Identification of relevant single-nucleotide polymorphisms in Pneumocystis jirovecii: Relationship with clinical data. Clin. Microbiol. Infect. 2010, 16, 878-884. [CrossRef] [PubMed]

48. Thomas, S.; Vivancos, R.; Corless, C.; Wood, G.; Beeching, N.J.; Beadsworth, M.B. Increasing frequency of Pneumocystis jirovecii pneumonia in renal transplant recipients in the United Kingdom: Clonal variability, clusters, and geographic location. Clin. Infect. Dis. 2011, 53, 307-308. [CrossRef]

49. Beser, J.; Botero-Kleiven, S.; Lebbad, M.; Hagblom, P.; Fernandez, V. A limited number of ITS haplotypes defines the diversity of Pneumocystis jirovecii strains in Sweden. Infect. Genet. Evol. 2011, 11, 948-954. [CrossRef]

50. Pliquett, R.U.; Asbe-Vollkopf, A.; Hauser, P.M.; Presti, L.L.; Hunfeld, K.P.; Berger, A.; Scheuermann, E.H.; Jung, O.; Geiger, H.; Hauser, I.A. A Pneumocystis jirovecii pneumonia outbreak in a single kidney-transplant center: Role of cytomegalovirus co-infection. Eur. J. Clin. Microbiol. Infect. Dis. 2012, 31, 2429-2437. [CrossRef]

51. Dimonte, S.; Berrilli, F.; D’Orazi, C.; D’Alfonso, R.; Placco, F.; Bordi, E.; Perno, C.F.; Di Cave, D. Molecular analysis based on $m t L S U-r R N A$ and DHPS sequences of Pneumocystis jirovecii from immunocompromised and immunocompetent patients in Italy. Infect. Genet. Evol. 2013, 14, 68-72. [CrossRef] [PubMed] 
52. de Armas, Y.; Friaza, V.; Capó, V.; Durand-Joly, I.; Govín, A.; de La Horra, C.; Dei-Cas, E.; Calderón, E.J. Low genetic diversity of Pneumocystis jirovecii among Cuban population based on two-locus mitochondrial typing. Med. Mycol. 2012, 50, 417-420. [CrossRef]

53. Curran, T.; McCaughey, C.; Coyle, P. V Pneumocystis jirovecii multilocus genotyping profiles in Northern Ireland. J. Med. Microbiol. 2013, 62, 1170-1174. [CrossRef]

54. Debourgogne, A.; Favreau, S.; Ladriere, M.; Bourry, S.; Machouart, M. Characteristics of Pneumocystis pneumonia in Nancy from January 2007 to April 2011 and focus on an outbreak in nephrology. J. Mycol. Med. 2014, 24, 19-24. [CrossRef] [PubMed]

55. Nankivell, B.J.; Firacative, C.; Kable, K.; Chen, S.C.-A.; Meyer, W. Molecular epidemiology linking multihospital clusters of opportunistic Pneumocystis jirovecii pneumonia. Clin. Infect. Dis. 2013, 57, 1058-1059. [CrossRef] [PubMed]

56. Rostved, A.A.; Sassi, M.; Kurtzhals, J.A.L.; Sørensen, S.S.; Rasmussen, A.; Ross, C.; Gogineni, E.; Huber, C.; Kutty, G.; Kovacs, J.A. Outbreak of Pneumocystis Pneumonia in renal and liver transplant patients caused by genotypically distinct strains of Pneumocystis jirovecii. Transplantation 2013, 96, 834-842. [CrossRef]

57. Chua, K.Y.L.; Halliday, C.L.; Grote, D.; Meyer, W.; Kesson, A.M.; Chen, S.C.A. Colonisation with Pneumocystis jirovecii in Australian infants. Pathol. RCPA 2015, 47, 489-490. [CrossRef] [PubMed]

58. Alanio, A.; Morio, F.; Gits-Muselli, M.; Desnos-Ollivier, M.; Maitte, C.; Bretagne, S. Short tandem repeat genotyping for P. jirovecii is more sensitive to mixed genotype than MLST. J. Mycol. Med. 2015, 25, 220-221. [CrossRef]

59. Depypere, M.; Saegeman, V.; Lagrou, K. Typing of Pneumocystis jirovecii by multilocus sequencing: Evidence of outbreak? Eur. J. Clin. Microbiol. Infect. Dis. 2016, 35, 911-916. [CrossRef]

60. Desoubeaux, G.; Dominique, M.; Morio, F.; Thepault, R.-A.; Franck-Martel, C.; Tellier, A.-C.; Ferrandière, M.; Hennequin, C.; Bernard, L.; Salamé, E. Epidemiological outbreaks of Pneumocystis jirovecii pneumonia are not limited to kidney transplant recipients: Genotyping confirms common source of transmission in a liver transplantation unit. J. Clin. Microbiol. 2016, 54, 1314-1320. [CrossRef]

61. Charpentier, E.; Garnaud, C.; Wintenberger, C.; Bailly, S.; Murat, J.-B.; Rendu, J.; Pavese, P.; Drouet, T.; Augier, C.; Malvezzi, P. Added value of next-generation sequencing for multilocus sequence typing analysis of a Pneumocystis jirovecii pneumonia outbreak. Emerg. Infect. Dis. 2017, 23, 1237-1245. [CrossRef] [PubMed]

62. Vindrios, W.; Argy, N.; Le Gal, S.; Lescure, F.-X.; Massias, L.; Le, M.P.; Wolff, M.; Yazdanpanah, Y.; Nevez, G.; Houze, S. Outbreak of Pneumocystis jirovecii infection among heart transplant recipients: Molecular investigation and management of an interhuman transmission. Clin. Infect. Dis. 2017, 65, 1120-1126. [CrossRef] [PubMed]

63. Sokulska, M.; Kicia, M.; Wesołowska, M.; Piesiak, P.; Kowal, A.; Lobo, M.L.; Kopacz, Ż.; Hendrich, A.B.; Matos, O. Genotyping of Pneumocystis jirovecii in colonized patients with various pulmonary diseases. Med. Mycol. 2018, 56, 809-815. [CrossRef]

64. Ricci, G.; Santos, D.W.; Kovacs, J.A.; Nishikaku, A.S.; de Sandes-Freitas, T.V.; Rodrigues, A.M.; Kutty, G.; Affonso, R.; Silva, H.T.; Medina-Pestana, J.O. Genetic diversity of Pneumocystis jirovecii from a cluster of cases of pneumonia in renal transplant patients: Cross-sectional study. Mycoses 2018, 61, 845-852. [CrossRef]

65. Singh, Y.; Mirdha, B.R.; Guleria, R.; Kabra, S.K.; Mohan, A.; Chaudhry, R.; Kumar, L.; Dwivedi, S.N.; Agarwal, S.K. Genetic polymorphisms associated with treatment failure and mortality in pediatric Pneumocystosis. Sci. Rep. 2019, 9, 1192. [CrossRef] [PubMed]

66. Nevez, G.; Guillaud-Saumur, T.; Cros, P.; Papon, N.; Vallet, S.; Quinio, D.; Minoui-Tran, A.; Pilorgé, L.; de Parscau, L.; Sizun, J. Pneumocystis primary infection in infancy: Additional French data and review of the literature. Med. Mycol. 2020, 58, 163-171. [CrossRef] [PubMed]

67. Sürgeç, E.; Can, H.; Döşkaya, M.; Karakavuk, M.; Atalay Şahar, E.; Değirmenci Döşkaya, A.; Pullukçu, H.; Taşbakan, M.; Sezai Taşbakan, M.; Akyol, D. Genotyping of Pneumocystis jirovecii isolates obtained from clinical samples by multilocus sequencing: A molecular epidemiology study conducted in Turkey. Arch. Microbiol. 2020, 202, 1647-1652. [CrossRef]

68. Le Gal, S.; Toubas, D.; Totet, A.; Dalle, F.; Abou Bacar, A.; Le Meur, Y.; Nevez, G. Pneumocystis infection outbreaks in organ transplantation units in France: A Nation-wide survey. Clin. Infect. Dis. 2020, 70, 2216-2220. [CrossRef] 
69. Szydłowicz, M.; Jakuszko, K.; Szymczak, A.; Piesiak, P.; Kowal, A.; Kopacz, Ż.; Wesołowska, M.; Lobo, M.L.; Matos, O.; Hendrich, A.B. Prevalence and genotyping of Pneumocystis jirovecii in renal transplant recipients-Preliminary report. Parasitol. Res. 2019, 118, 181-189. [CrossRef]

70. Muñoz, C.; Zuluaga, A.; Restrepo, A.; Tobón, A.; Cano, L.E.; Gonzalez, A. Molecular diagnosis and detection of Pneumocystis jirovecii DHPS and DHFR genotypes in respiratory specimens from Colombian patients. Diagn. Microbiol. Infect. Dis. 2012, 72, 204-213. [CrossRef]

71. Taylor, S.M.; Meshnick, S.R.; Worodria, W.; Andama, A.; Cattamanchi, A.; Davis, J.L.; Yoo, S.D.; Byanyima, P.; Kaswabuli, S.; Goodman, C.D. Low prevalence of Pneumocystis pneumonia (PCP) but high prevalence of Pneumocystis dihydropteroate synthase (dhps) gene mutations in HIV-infected persons in Uganda. PLoS ONE 2012, 7, e49991. [CrossRef]

72. Liu, Y.; Fahle, G.A.; Kovacs, J.A. Inability to culture Pneumocystis jirovecii. MBio 2018, 9, e00939-18. [CrossRef] [PubMed]

73. Roux, P.; Lavrard, I.; Poirot, J.L.; Chouaid, C.; Denis, M.; Olivier, J.L.; Nigou, M.; Miltgen, M. Usefulness of PCR for detection of Pneumocystis carinii DNA. J. Clin. Microbiol. 1994, 32, 2324-2326. [CrossRef] [PubMed]

74. Xue, T.; Ma, Z.; Liu, F.; Du, W.-Q.; He, L.; Ma, L.; An, C.-L. Genotyping of Pneumocystis jirovecii by use of a new simplified nomenclature system based on the internal transcribed spacer regions and 5.8S rRNA gene of the rRNA operon. J. Clin. Microbiol. 2019, 57, 1-11. [CrossRef]

75. Valero, C.; Buitrago, M.J.; Gits-Muselli, M.; Benazra, M.; Sturny-Leclère, A.; Hamane, S.; Guigue, N.; Bretagne, S.; Alanio, A. Copy number variation of mitochondrial DNA genes in Pneumocystis jirovecii according to the fungal load in BAL specimens. Front. Microbiol. 2016, 7, 1413. [CrossRef] [PubMed]

76. Alanio, A.; Gits-Muselli, M.; Mercier-Delarue, S.; Dromer, F.; Bretagne, S. Diversity of Pneumocystis jirovecii during infection revealed by ultra-deep pyrosequencing. Front. Microbiol. 2016, 7, 733. [CrossRef]

77. Ma, L.; Cissé, O.H.; Kovacs, J.A. A molecular window into the biology and epidemiology of Pneumocystis spp. Clin. Microbiol. Rev. 2018, 31, 1-49. [CrossRef]

78. Nahimana, A.; Francioli, P.; Blanc, D.S.; Bille, J.; Wakefield, A.E.; Hauser, P.M. Determination of the copy number of the nuclear rDNA and Beta-tubulin genes of Pneumocystis carinii f. sp. hominis using PCR multicompetitors. J. Eukaryot. Microbiol. 2000, 47, 368-372. [CrossRef]

79. Brancart, F.; Rodriguez-Villalobos, H.; Fonteyne, P.-A.; Peres-Bota, D.; Liesnard, C. Quantitative TaqMan PCR for detection of Pneumocystis jiroveci. J. Microbiol. Methods 2005, 61, 381-387. [CrossRef]

80. Morilla, R.; González-Magaña, A.; Friaza, V.; de Armas, Y.; Medrano, F.J.; Calderón, E.; de la Horra, C. Genetic polymorphisms of Superoxide Dismutase locus of Pneumocystis jirovecii in Spanish population. Front. Public Health 2019, 7, 292. [CrossRef]

81. Huang, L.; Crothers, K.; Atzori, C.; Benfield, T.; Miller, R.; Rabodonirina, M.; Helweg-Larsen, J. Dihydropteroate synthase gene mutations in Pneumocystis and sulfa resistance. Emerg. Infect. Dis. 2004, 10, 1721-1728. [CrossRef]

82. Nahimana, A.; Rabodonirina, M.; Bille, J.; Francioli, P.; Hauser, P.M. Mutations of Pneumocystis jirovecii Dihydrofolate reductase associated with failure of prophylaxis. Antimicrob. Agents Chemother. 2004, 48, 4301-4305. [CrossRef] [PubMed]

83. Matos, O.; Esteves, F. Pneumocystis jirovecii multilocus gene sequencing: Findings and implications. Future Microbiol. 2010, 5, 1257-1267. [CrossRef]

84. Costa, M.C.; Esteves, F.; Antunes, F.; Matos, O. Genetic characterization of the Dihydrofolate reductase gene of Pneumocystis jirovecii isolates from Portugal. J. Antimicrob. Chemother. 2006, 58, 1246-1249. [CrossRef] [PubMed]

85. Sunkin, S.M.; Stringer, J.R. Translocation of surface antigen genes to a unique telomeric expression site in Pneumocystis carinii. Mol. Microbiol. 1996, 19, 283-295. [CrossRef]

86. Procop, G.W.; Haddad, S.; Quinn, J.; Wilson, M.L.; Henshaw, N.G.; Reller, L.B.; Artymyshyn, R.L.; Katanik, M.T.; Weinstein, M.P. Detection of Pneumocystis jiroveci in respiratory specimens by four staining methods. J. Clin. Microbiol. 2004, 42, 3333-3335. [CrossRef] [PubMed]

87. Wakefield, A.E.; Pixley, F.J.; Banerji, S.; Sinclair, K.; Miller, R.F.; Moxon, E.R.; Hopkin, J.M. Amplification of mitochondrial ribosomal RNA sequences from Pneumocystis carinii DNA of rat and human origin. Mol. Biochem. 1990, 43, 69-76. [CrossRef] 
88. Thompson, J.D.; Higgins, D.G.; Gibson, T.J. CLUSTAL W: Improving the sensitivity of progressive multiple sequence alignment through sequence weighting, position-specific gap penalties and weight matrix choice. Nucleic Acids Res. 1994, 22, 4673-4680. [CrossRef]

89. Kumar, S.; Stecher, G.; Li, M.; Knyaz, C.; Tamura, K. MEGA X: Molecular Evolutionary Genetics Analysis across computing platforms. Mol. Biol. Evol. 2018, 35, 1547-1549. [CrossRef]

90. Fisher, M.E.; Scesney, P.E. Visibility of Critical-Exponent Renormalization. Phys. Rev. A 1970, $3,825$. [CrossRef]

91. Silvestro, D.; Michalak, I. raxmlGUI: A graphical front-end for RAxML. Org. Divers. Evol. 2012, 12, $335-337$. [CrossRef]

92. Kumar, S.; Stecher, G.; Tamura, K. MEGA7: Molecular Evolutionary Genetics Analysis version 7.0. Mol. Biol. Evol. 2015, 33, 1870-1874. [CrossRef]

93. De Boer, M.G.J.; de Fijter, J.W.; Kroon, F.P. Outbreaks and clustering of Pneumocystis pneumonia in kidney transplant recipients: A systematic review. Med. Mycol. 2011, 49, 673-680. [PubMed]

94. Kim, J.E.; Han, A.; Lee, H.; Ha, J.; Kim, Y.S.; Han, S.S. Impact of Pneumocystis jirovecii pneumonia on kidney transplant outcome. BMC Nephrol. 2019, 20, 212. [CrossRef] [PubMed]

95. Alanio, A.; Hauser, P.M.; Lagrou, K.; Melchers, W.J.G.; Helweg-Larsen, J.; Matos, O.; Cesaro, S.; Maschmeyer, G.; Einsele, H.; Donnelly, J.P. ECIL guidelines for the diagnosis of Pneumocystis jirovecii pneumonia in patients with haematological malignancies and stem cell transplant recipients. J. Antimicrob. Chemother. 2016, 71, 2386-2396. [CrossRef] [PubMed]

96. Alanio, A.; Desoubeaux, G.; Sarfati, C.; Hamane, S.; Bergeron, A.; Azoulay, E.; Molina, J.M.; Derouin, F.; Menotti, J. Real-time PCR assay-based strategy for differentiation between active Pneumocystis jirovecii pneumonia and colonization in immunocompromised patients. Clin. Microbiol. Infect. 2011, 17, 1531-1537. [CrossRef]

97. Lu, Y.; Ling, G.; Qiang, C.; Ming, Q.; Wu, C.; Wang, K.; Ying, Z. PCR diagnosis of Pneumocystis pneumonia: A bivariate meta-analysis. J. Clin. Microbiol. 2011, 49, 4361-4363. [CrossRef]

98. Hunter, P.R.; Gaston, M.A. Numerical index of the discriminatory ability of typing systems: An application of Simpson's index of diversity. J. Clin. Microbiol. 1988, 26, 2465-2466. [CrossRef]

99. Le Gal, S.; Damiani, C.; Rouillé, A.; Grall, A.; Tréguer, L.; Virmaux, M.; Moalic, E.; Quinio, D.; Moal, M.-C.; Berthou, C. A cluster of Pneumocystis infections among renal transplant recipients: Molecular evidence of colonized patients as potential infectious sources of Pneumocystis jirovecii. Clin. Infect. Dis. 2012, 54, e62-e71. [CrossRef]

100. Helweg-Larsen, J.; Benfield, T.L.; Eugen-Olsen, J.; Lundgren, J.D.; Lundgren, B. Effects of mutations in Pneumocystis carinii Dihydropteroate synthase gene on outcome of AIDS-associated P. carinii pneumonia. Lancet 1999, 354, 1347-1351. [CrossRef]

101. Suárez, I.; Roderus, L.; van Gumpel, E.; Jung, N.; Lehmann, C.; Fätkenheuer, G.; Hartmann, P.; Plum, G.; Rybniker, J. Low prevalence of DHFR and DHPS mutations in Pneumocystis jirovecii strains obtained from a German cohort. Infection 2017, 45, 341-347. [CrossRef]

102. Iliades, P.; Meshnick, S.R.; Macreadie, I.G. Mutations in the Pneumocystis jirovecii DHPS gene confer cross-resistance to sulfa drugs. Antimicrob. Agents Chemother. 2005, 49, 741-748. [CrossRef]

103. Ponce, C.A.; Chabé, M.; George, C.; Cárdenas, A.; Durán, L.; Guerrero, J.; Bustamante, R.; Matos, O.; Huang, L.; Miller, R.F. High prevalence of Pneumocystis jirovecii Dihydropteroate synthase gene mutations in patients with a first episode of Pneumocystis pneumonia in Santiago, Chile, and clinical response to trimethoprim-sulfamethoxazole therapy. Antimicrob. Agents Chemother. 2017, 61, e01290-16. [CrossRef]

104. Rabodonirina, M.; Nahimana, A.; Weber, R.; Francioli, P.; Bille, J.; Hauser, P.M. Geographical variation in the prevalence of Pneumocystis jirovecii Dihydropteroate synthase mutations within Western Europe. J. Eukaryot. Microbiol. 2006, 53, S112-S113. [CrossRef]

Publisher's Note: MDPI stays neutral with regard to jurisdictional claims in published maps and institutional affiliations. 